\title{
Oct4 kinetics predict cell lineage patterning in the early mammalian embryo
}

\section{Nicolas Plachta, Tobias Bollenbach, Shirley Pease, Scott E. Fraser and Periklis Pantazis}

Nat. Cell Biol. 13, 117-123 (2011); published online 23 January 2011; corrected after print 28 January 2011;

In the version of this article initially published online and in print, the values for $k_{\text {out }}$ and $k_{\text {in }}$ in table 1 were incorrect. The correct values are $\left(\times 10^{-3} \mathrm{~s}^{-1}\right)$. This error has been corrected in both the HTML and PDF versions of the article. 